\title{
EDUKASI LATIHAN PADA KAKI DAN BETIS PADA PENDERITA DIABETES MELITUS TERHADAP TINGKAT SENSIBILITAS KAKI
}

\author{
Suratun', Ika Guslanda Bustam² \\ ${ }^{1}$ Dosen Program Studi Ilmu Keperawatan, IKesT Muhammadiyah Palembang \\ ${ }^{2}$ Dosen Program Studi DIII Fisioterapi, IKesT Muhammadiyah Palembang \\ Email: sur.rafii.0377@gmail.com, ikaguslanda@gmail.com
}

\begin{abstract}
ABSTRAK
Penderita diabetes dengan kadar glukosa darah yang tinggi secara konsisten dapat menyebabkan penyakit serius yang akan memengaruhi jantung dan pembuluh darah, mata, ginjal, saraf dan gigi. Selain itu, pada penderita DM juga memiliki risko infeksi lebih tinggi pada kaki. Oleh karena itu tujuan kegiatan pengabdian masysrakat ini adalah meningkatkan kemauan dan kemampuan untuk menjalankan latihan pada kaki dan betis dengan Towel curl exercise dan heel calp rise exercise untuk mengurangi komplikasi pada penderita Diabetes Melitus terutama pada kaki. Metode yang diterapkan adalah ceramah dengan mengedukasi serta mempraktikan langsung di depan para peserta kegiatan. Hasil kegiatan ini diketahui terdapat peningkatan kesadaran pada masyarakat untuk melakukan aktivitas fisik pada penderita diabetes mellitus.
\end{abstract}

Kata Kunci: Diabetes Militus, Latihan Kaki, Towel Curl Exercise, Heel Calp Rise Exercise

\section{EDUCATION OF EXERCISE ON THE FEET AND CALF IN DIABETES MELLITUS PATIENTS ON THE LEVEL OF FEET SENSIBILITY}

\begin{abstract}
Diabetics with consistently high blood glucose levels can cause serious diseases that will affect the heart and blood vessels, eyes, kidneys, nerves and teeth. In addition, DM sufferers also have a higher risk of infection of the legs. Therefore, the purpose of this community service activity is to increase the willingness and ability to exercises on the legs and calves with Towel curl exercise and heel calp rise exercise to reduce complications in people with Diabetes Mellitus, especially in the legs. The method applied is lectures by educating and practicing directly in front of the participants of the activity. The results of this activity are known to increase awareness in the community to perform physical activity in people with diabetes mellitus.
\end{abstract}

Keywords: Diabetes Mellitus, Leg Exercises, Towel curl exercise, Heel Calp Rise Exercise

\section{PENDAHULUAN}

Diabetes mellitus (DM) merupakan penyakit kronis yang tidak ditularkan dari orang ke orang. Penyakit ini juga disebut sebagai penyakit silent killer karena sering tidak disadari oleh penderita sampai dengan terjadinya komplikasi (Yuliastuti et al., 2017). Penyakit DM biasanya berjalan dengan lambat dengan gejala-gejala ringan sampai dengan berat, bahkan dapat menyebabkan kematian akibat komplikasi akut maupun kronis (Lubis, 2019).

Diabetes mellitus atau kencing manis merupakan penyakit menahun yang ditandai dengan meningkatnya kadar glukosa darah dan gangguan metabolisme karbohidrat, lemak, dan protein yang disebabkan oleh kekurangan hormon insulin (Soep \& Triwibowo, 2015). Penderita diabetes dengan kadar glukosa darah yang tinggi secara konsisten dapat menyebabkan penyakit serius yang akan 
memengaruhi jantung dan pembuluh darah, mata, ginjal, saraf dan gigi. Selain itu, pada penderita DM juga memiliki risko infeksi lebih tinggi (Azizah et al., 2019). Hal ini dikarenakan karena penyakit DM merupakan faktor yang dapat menyebabkan terjadinya risiko penyakit jantung, gagal ginjal dan stroke. Badan Penyelenggara Jaminan Sosial Kesehatan (BPJS-K) melaporkan bahwa terjadi peningkatan defisit anggaran sebesar Rp 9 triliun pada tahun 2017 dari sebelumnya Rp 3,31 triliun pada tahun 2014. Peningkatan jumlah anggaran ini bukan hanya disebabkan oleh jumlah peserta jaminan kesehatan yang meningkat tetapi juga dikarenakan oleh pemasukan yang tidak sesuai, pengeluaran yang meningkat karena tingginya perawatan penyakit. Penyakit DM dan komplikasinya telah menghabiskan 33\% dari total anggaran sistem pelayanan kesehatan nasional pada tahun 2015.

Berdasarkan data Internasional of Diabetic Federation (IDF) tahun 2019, tingkat prevalensi global penderita diabetes mellitus pada tahun 2019 sebesar 9,3\% atau sekitar 463 juta kasus dari jumlah keseluruhan penduduk di dunia. Angka ini diperkirakan akan terus meningkat pada tahun 2030 dengan 578 juta kasus dan akan mengalami peningkatan sekitar 700 juta kasus pada tahun 2045. Saat ini, Indonesia merupakan negara yang menempati urutan ke 7 dengan penderita diabetes mellitus sebanyak 10,7 juta orang setelah Cina, India, Amerika Serikat, Pakistan, Brazil, dan Mexico.

Sementara itu, data dari Riset Kesehatan Dasar (Riskesdas, 2018) menunjukkan bahwa terjadi peningkatan prevalensi diabetes mellitus di Indonesia berdasarkan diagnosis dokter pada penduduk umur $\geq 15$ tahun dari 1,5\% di tahun 2013 menjadi 2\% di tahun 2018. Data Sample Registration Survey tahun 2016 menunjukkan bahwa diabetes mellitus merupakan penyebab kematian terbesar nomor 3 di Indonesia dengan presentase sebesar 7,9\% setelah penyakit Serebrovaskular (19,9\%) dan penyakit Jantung Iskemik (13,3\%).

Provinsi Sumatera Selatan menempati urutan ke 29 dengan penderita diabetes mellitus dengan provinsi tertinggi yaitu DKI Jakarta dan provinsi terendah Nusa Tenggara Timur. Prevalensi penyakit diabetes mellitus di provinsi sumatera selatan berdasarkan diagnosis dokter pada penduduk umur $\geq 15$ tahun menunjukkan peningkatan dari $0,9 \%$ di tahun 2013 menjadi 1,4\% di tahun 2018 (Riskesdas, 2018).

Berdasarkan data yang diperoleh dari Dinas Kesehatan Kota Palembang, jumlah penderita diabetes mellitus pada tahun 2013 sebanyak 21.418 orang dan mengalami peningkatan pada tahun 2018 sebanyak 33.676 orang. Saat ini, diabetes mellitus menempati urutan ke 7 dari 10 penyakit terbanyak di kota Palembang setelah penyakit Infeksi Saluran Pernapasan Atas (ISPA), Mialgia, Hipertensi Esensia, Dermatitis dan Ekstrim, Gastritis, Organic Brain Syndrome (OBS), dan Reumatik (Dinkes Kota Palembang, 2018). 
Tingginya prevalensi diabetes melitus disebabkan oleh beberapa faktor risiko yang tidak dapat diubah seperti faktor genetik, umur dan jenis kelamin. Sedangkan faktor risiko yang dapat diubah seperti tingkat pendidikan, pekerjaan, aktivitas fisik, kebiasaan merokok, mengonsumsi alkohol dan indeks massa tubuh. Penyakit yang akan ditimbulkan antara lain penyakit jantung, sakit ginjal, gangguan penglihatan, katarak, impotensi seksual, luka sulit sembuh dan membusuk, infeksi paru-paru, gangguan pembuluh darah, stroke dan sebagainya (Restyana, 2015). Penyebab diabetes melitus paling banyak ditemui adalah pola hidup yang tidak sehat. Oleh karena itu perlu adanya upaya pencegahan penyakit diabetes melitus ini. Tindakan pencegahan semakin penting dilakukan dalam menurunkan jumlah penderita diabetes melitus yang semakin lama kenaikannya semakin signifikan (Susanti \& Hudiyawati, 2019).

Faktor lain yang mempengaruhi risiko terjadinya diabetes melitus adalah gaya hidup seseorang. Perilaku tersebut diantaranya yaitu aktivitas fisik yang buruk dan pola makan yang buruk seperti makan makanan tinggi lemak, manis, tidak mengkonsumsi sayur serta buah-buahan. Faktor tersebut bisa dirubah atau dapat dicegah dengan pengaturan pola makan yang baik dan olahraga secara teratur sehingga dapat menurunkan prevalensi terjadinya diabetes melitus. Jenis diabetes melitus yang paling banyak diderita sekitar 90-95\% merupakan diabetes melitus tipe 2 yaitu tipe diabetes yang seharusnya bisa dicegah (Gina, 2019).

Pencegahan dan pengendalian diabetes melitus di Indonesia dilakukan supaya orang yang sehat tetap sehat dan menjaga kesehatannya, orang yang sudah memiliki faktor risiko dapat mengontrol faktor risiko tersebut sehingga tidak terkena diabetes, dan orang yang sudah menderita diabetes dapat mengontrol penyakitnya sehingga tidak akan ada komplikasi atau kematian dini (Infodatin, 2020).

\section{MASALAH}

Kurangnya aktivitas fisik (olahraga) sehingga mengakibat kurangnya sensitivitas terhadap insulin yang dapat mengakibatkan komplikasi pada pasien Diabetes melitus terutama pada kaki. Upaya pencegahan dapat dilakukan dengan beberapa cara yaitu: menerapkan pola makan sehat dan menjalani olah raga secara rutin (Susanti \& Hudiyawati, 2019).

Olahraga secara teratur 3-4 kali seminggu dengan durasi kurang lebih 30 menit dapat menjaga kebugaran dan menurunkan berat badan. Selain itu, dapat untuk memperbaiki sensitivitas insulin, sehingga akan memperbaiki kendali glukosa darah. Latihan jasmani yang bersifat aerobik seperti jalan kaki, bersepeda santai, jogging, dan berenang. Untuk yang relatif sehat, intensitas latihan jasmani bisa ditingkatkan, sementara yang sudah mendapatkan komplikasi diabetes melitus dapat dikurangi. Salah satu olahraga yang bisa dilakukan adalah senam, senam diabetes sangat penting dilakukan karena senam tersebut bisa mengolah semua organ tubuh manusia, mulai otak hingga 
ujung kaki. Sebab dampak penyakit diabetes menyerang seluruh tubuh. Dampak paling ringan adalah kaki kesemutan. Sedangkan yang terparah adalah menderita stroke.

\section{METODE PELAKSANAAN}

Metode pelaksanaan kegiatan pengabdian masyarakat ini adalah pendidikan kesehatan melalui ceramah, praktik dan tanya jawab. Waktu pelaksanaan yaitu di bulan Februari 2021. Sasaran kegiatan pengabdian masyarakat ini adalah masyarakat yang berada di Kabupaten Kota Palembang. Program latihan pada betis dan kaki dengan Heel Raise Exercise dan Towel Curl Exercise adalah sebagai berikut:

\section{Heel Raise Exercise}

Heel Raise Exercise adalah program latihan untuk meningkatkan kekuatan otot-otot stabilisator pembentuk kaki serta memiliki dampak positif pada kinerja otot antara lain adalah perbaikan dalam keseimbangan dan sensibilitas kaki (Kisner, dkk 2007).

Manfaat latihan Heel Raise Exercise dianggap dapat meningkatkan kekuatan otot terutama otot gastrocnemius dan otot plantar flexor kaki. Heel Raise Exercise menimbulkan efek pada saraf dan skeletal karena adanya rangsangan propioseptif.

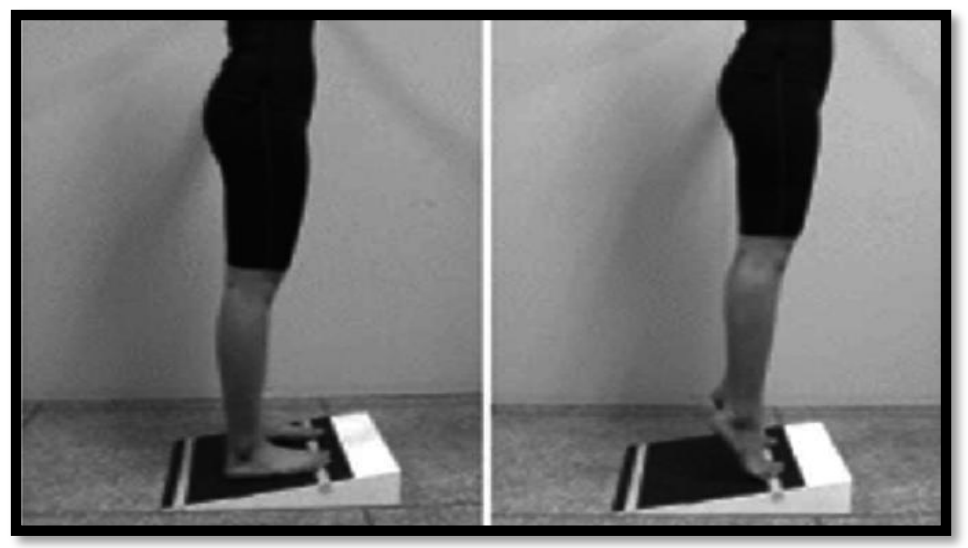

Gambar 1 Heel Raise Exercise

(Patterson, dkk 2010)

\section{Towel Curl Exercise}

Towel Curl Exercise merupakan suatu bentuk latihan Strengthening (penguatan) dimana latihan tersebut merupakan latihan yang digunakan untuk mengaktivasi otot dengan maksimal dan terfokus pada gerakan yang melibatkan kerja otot inti. Ketika otot teraktivasi, maka akan menciptakan stabilisasi yang baik sehingga dapat meningkatkan sensibilitas kulit pada kaki (Zaidah, 2018).

Manfaat dari latihan Towel cur exercise yaitu untuk penguatan $m$. Flexor digitorum longus dan brevis, $m$. Lumbricales dan m.flexor hallucis longus. Selain dari penguatan otot, latihan ini dapat 
meningkatkan fleksibilitas pada otot dan sensibilitas kaki. Latihan ini juga tentunya dapat melatih cengkraman pada jari-jari kaki dan meningkatkan stabilitas ankle pada saat berjalan dan menaiki tangga.

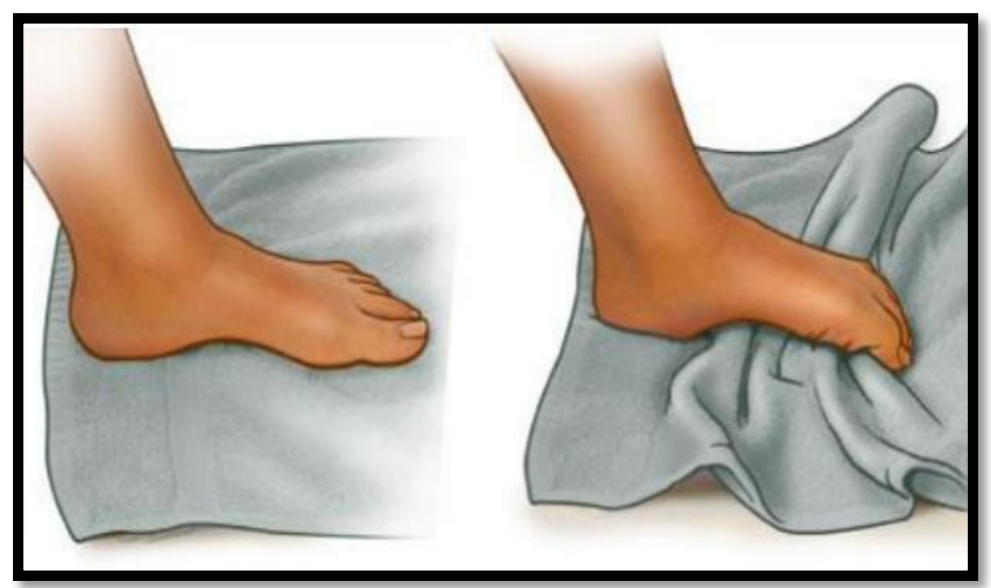

Gambar 2 Towel Curl Exercise

Zaidah (2018)

Tabel 1

Dosis Latihan

\begin{tabular}{|c|c|c|c|c|}
\hline No & Minggu & Dosis & Heel Raise Exercise & Towel Curl Exercise \\
\hline 1. & Minggu ke 1 & $\begin{array}{l}\text { Frekuensi } \\
\text { Repitisi } \\
\text { Rest } \\
\text { Time }\end{array}$ & $\begin{array}{l}2 \text { kali per minggu } \\
5 \text { kali pengulangan } \\
1 \text { menit/set } \\
6 \text { detik }\end{array}$ & $\begin{array}{l}2 \text { kali per minggu } \\
5 \text { kali pengulangan } \\
1 \text { menit/set } \\
5 \text { detik }\end{array}$ \\
\hline 2. & Minggu ke 2 & $\begin{array}{l}\text { Frekuensi } \\
\text { Repitisi } \\
\text { Rest } \\
\text { Time } \\
\end{array}$ & $\begin{array}{l}2 \text { kali per minggu } \\
5 \text { kali pengulangan } \\
1 \text { menit/set } \\
6 \text { detik }\end{array}$ & $\begin{array}{l}2 \text { kali per minggu } \\
5 \text { kali pengulangan } \\
1 \text { menit/set } \\
5 \text { detik }\end{array}$ \\
\hline 3. & Minggu ke 3 & $\begin{array}{l}\text { Frekuensi } \\
\text { Repitisi } \\
\text { Rest } \\
\text { Time }\end{array}$ & $\begin{array}{l}2 \text { kali per minggu } \\
5 \text { kali pengulangan } \\
1 \text { menit/set } \\
6 \text { detik }\end{array}$ & $\begin{array}{l}2 \text { kali per minggu } \\
5 \text { kali pengulangan } \\
1 \text { menit/set } \\
5 \text { detik }\end{array}$ \\
\hline 4. & Minggu ke 4 & $\begin{array}{l}\text { Frekuensi } \\
\text { Repitisi } \\
\text { Rest } \\
\text { Time }\end{array}$ & $\begin{array}{l}2 \text { kali per minggu } \\
5 \text { kali pengulangan } \\
1 \text { menit/set } \\
6 \text { detik }\end{array}$ & $\begin{array}{l}2 \text { kali per minggu } \\
5 \text { kali pengulangan } \\
1 \text { menit/set } \\
5 \text { detik }\end{array}$ \\
\hline 5. & Minggu ke 5 & $\begin{array}{l}\text { Frekuensi } \\
\text { Repitisi } \\
\text { Rest } \\
\text { Time }\end{array}$ & $\begin{array}{l}2 \text { kali per minggu } \\
5 \text { kali pengulangan } \\
1 \text { menit/set } \\
6 \text { detik }\end{array}$ & $\begin{array}{l}2 \text { kali per minggu } \\
5 \text { kali pengulangan } \\
1 \text { menit/set } \\
5 \text { detik }\end{array}$ \\
\hline 6. & Minggu ke 6 & $\begin{array}{l}\text { Frekuensi } \\
\text { Repitisi } \\
\text { Rest } \\
\text { Time }\end{array}$ & $\begin{array}{l}2 \text { kali per minggu } \\
5 \text { kali pengulangan } \\
1 \text { menit/set } \\
6 \text { detik }\end{array}$ & $\begin{array}{l}2 \text { kali per minggu } \\
5 \text { kali pengulangan } \\
1 \text { menit/set } \\
5 \text { detik }\end{array}$ \\
\hline
\end{tabular}

Sumber : Zaidah dan Ariani (2018) 


\section{HASIL DAN PEMBAHASAN}

Hilangnya sensasi (penurunan sensibilitas) merupakan salah satu faktor utama resiko terjadinya ulkus, tetapi terdapat beberapa faktor resiko lain yang juga turut berperan yaitu Keadaan hiperglikemia yang tidak terkontrol, usia pasien yang lebih dari 40 tahun, riwayat ulkus kaki atau amputasi, penurunan denyut nadi perifer, riwayat merokok, deformitas anatomis atau bagian yang menonjol (seperti bunion dan kalus) (Smeltzer and Bare, 2002). Latihan pada kaki dan betis yang dianjurkan pada penderita diabetes mellitus yang mengalami gangguan sirkulasi dan neuropati adalah dengan Heel Raise Exercise dan Towel Curl Exercise dan mencegah terjadinya luka pada merupakan salah satu tindakan yang dapat diberikan untuk mencegah komplikasi pada kaki. Karena adanya komplikasi yang disebut neuropati, pasien diabetes mengalami penurunan sensitivitas dan intoleransi terhadap dingin di kaki mereka. Neuropati terjadi ketika suplai darah ke ujung saraf kecil di kaki dan tangan berhenti atau berkurang (Echeverry, 2007).

Jika masalah sensibilitas pada kaki penderita diebetes tidak segera diatasi dan tidak dilakukan penanganan dengan benar maka akan menyebabkan kaki diabetik (ulkus kaki) bahkan dapat mengalami nekrosis jaringan yang berakhir pada amputasi (Tarwoto, dkk 2012). Untuk mengurangi beratnya gejala sensibilitas pada kaki penderita diebetes dibutuhkan tindakan pencegahan. Salah satu tindakan pencegahan yang dapat dilakukan yaitu melakukan latihan pada kaki dengan benar (Tarwoto, dkk 2012).

Menurut Waspadji (2012) latihan pada kaki dan betis dengan Heel Raise Exercise dan Towel Curl Exercise merupakan salah satu terapi yang bertujuan untuk melancarkan peredaran darah yang terganggu, karena latihan tersebut dapat membantu memperbaiki peredaran darah yang terganggu dan memperkuat otot-otot kecil kaki pada pasien diabetes mellitus dengan neuropati. Selain itu dapat memperkuat otot betis dan otot paha, juga mengatasi keterbatasan gerak sendi dan mencegah terjadinya deformitas.

Rata-rata nilai sensibilitas kaki pada penderita DM yang mengikuti kegiatan pengabdian masyarakat ini sebelum dan sesudah diberikan latihan pada kaki dan betis dengan Heel Raise Exercise dan Towel Curl Exercise terjadi penurunan. Terdapat perbedaan skor sensibilitas sebelum dan sesudah diberikan latihan pada kaki dan betis dengan Heel Raise Exercise dan Towel Curl Exercise.

Penurunan skor neuropati tersebut sejalan dengan penelitian oleh Satriadi (2013) yang telah melakukan senam kaki selama 6 minggu terjadi penurunan yang bermakna terhadap neuropati pada pasien dengan diabetes yang signifikan setelah diberikan senam kaki.

\section{Dokumentasi Kegiatan}




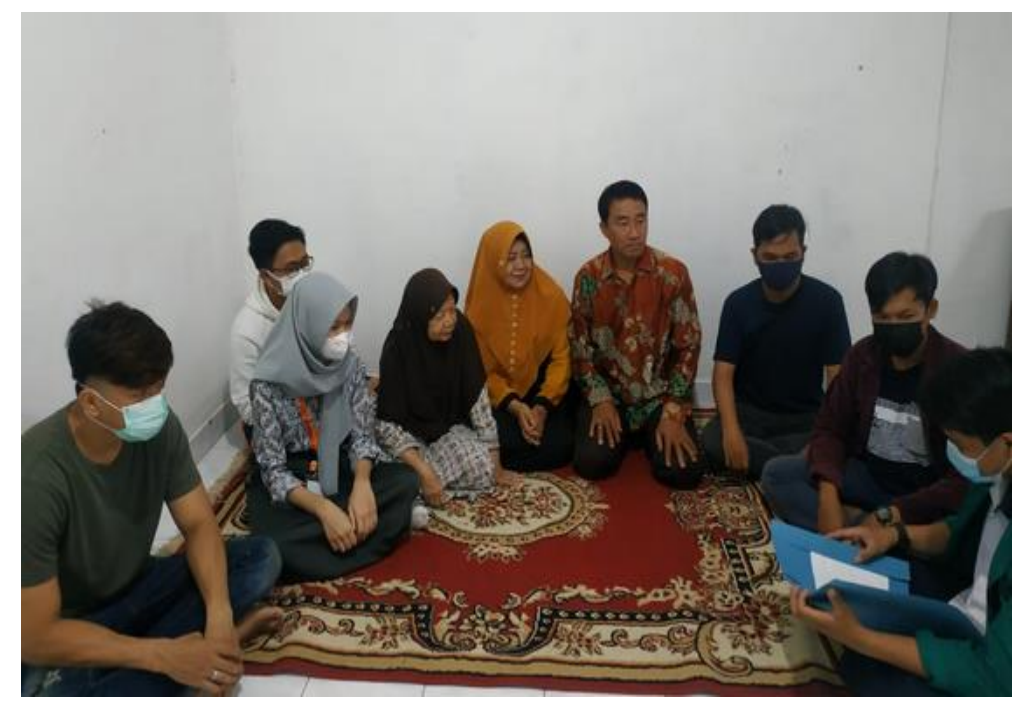

Gambar 3

Pemberian Arahan Kepada para Participants

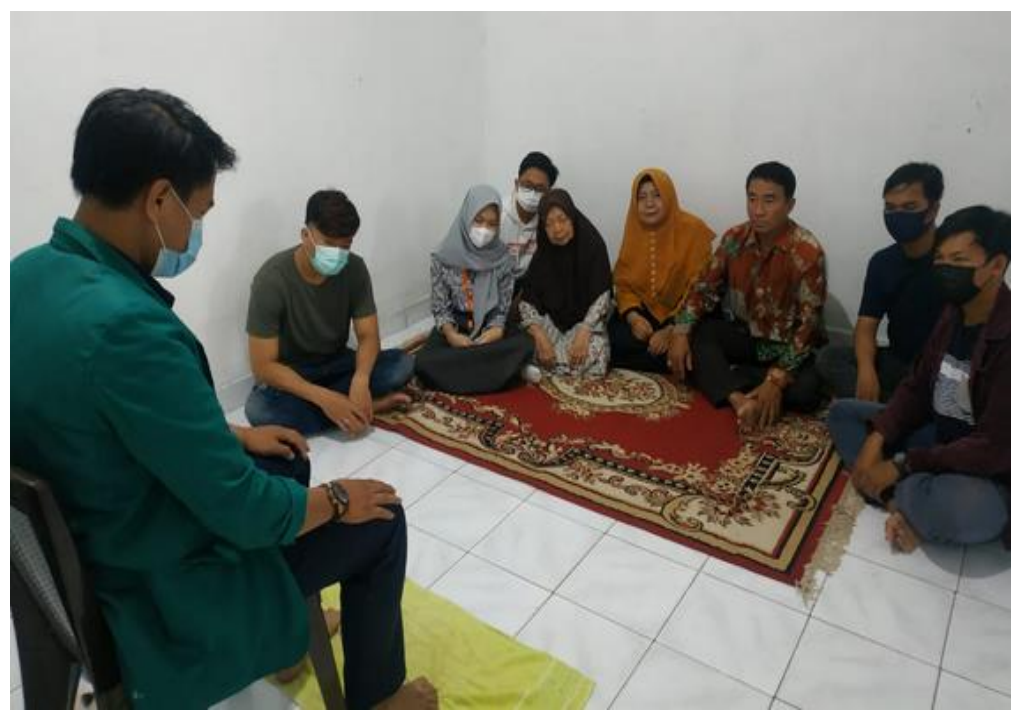

Gambar 3

Mempraktikan Gerakan Towel Curl Exercise

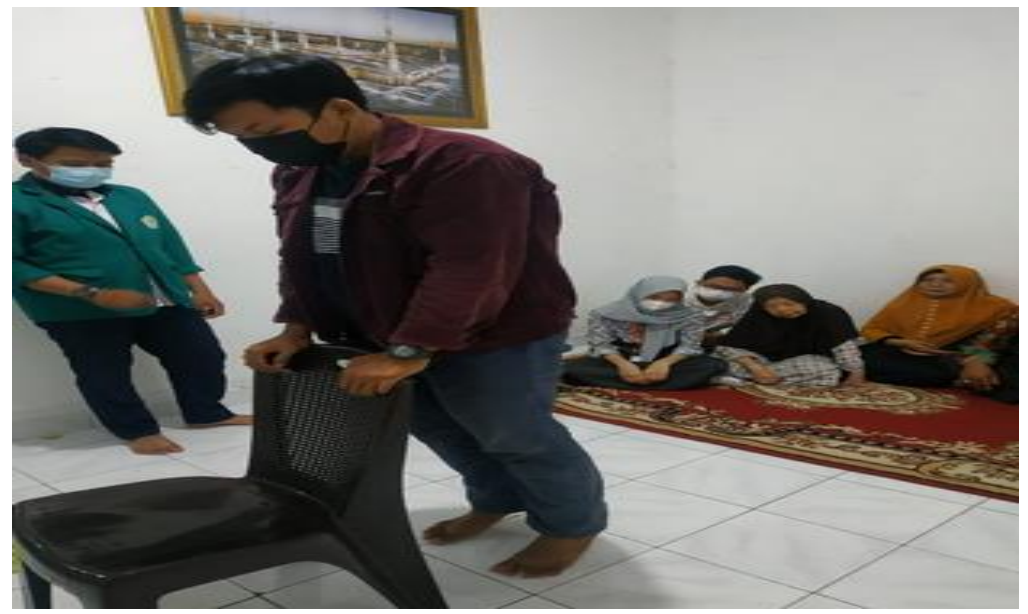




\section{Gambar 4 \\ Mempraktikan Gerakan Heel Raise Exercise}

\section{KESIMPULAN}

Latihan pada kaki dan betis sebaiknya wajib dilakukan oleh setiap orang yang menderita diabetes melitus. Hal ini dikarenakan penderita diabetes terjadi penurunan sensibilitas pada kaki yang membuat mereka sangat rentan terkena luka pada kaki, dimana proses penyembuhan luka tersebut juga membutuhkan waktu yang lama. Sehingga dengan melakukan latihan pada kaki dan betis dengan baik dan rutin, akan mengurangi resiko terjadinya komplikasi pada kaki.

Oleh karena itu latihan pada kaki dan betis dengan Heel Raise Exercise dan Towel Curl Exercise yang baik dapat mencegah terjadinya penurunan sensibilitas pada kaki diabetik, karena latihan tersebut dapat meningkatkan sirkulasi darah dan meningkatkan kekuatan otot-otot kaki. Hal ini dapat mencegah terjadinya masalah pada kaki yang dapat menyebabkan ulkus kaki serta resiko buruk lainnya. Karena mencegah terjadinya kaki diabetik lebih baik daripada proses penyembuhannya. Karena proses penyembuhan kaki diabetik membutuhkan waktu yang lama.

\section{UCAPAN TERIMA KASIH}

Penulis mengucapkan banyak terimakasih kepada pimpinan IKesT Muhammadiyah Palembang atas dana hibah pengabdian masyarakat yang telah diberikan sehingga penulis dapat melakukan kegiatan pengabdian masyarakat ini. Selain itu, penulis juga ingin mengucapkan banyak terimakasih kepada seluruh team yang telah membantu serta memfasilitasi kegiatan ini.

\section{DAFTAR PUSTAKA}

Aini, N., \& Aridiana, L. M. (2016). Sistem Endokrin dengan Pendekatan Nanda NIC NOC. Jakarta: Salemba Medika.

BPJS Kesehatan. BPJS Kesehatan. (2018). bpjs-kesehatan.go.id. https://bpjs-kesehatan.go.id/bpjs/.

[Diakses pada 11 Desember 2020]

Damayanti, S. (2016). Diabetes Mellitus \& Penatalaksanaan Keperawatan. Yogyakarta: Nuha Medika.

Dinkes Kota Palembang. (2018). Profil Kesehatan Tahun 2018 (Data 2017).

IDF (International Diabetes Federation). (2019). IDF Diabetes Atlas: 9th Edition. https://www.diabetesatlas.org/upload/resources/2019/IDF_Atlas_9th_Edition_2019.pdf. [Diakses 21 November 2020].

KEMENKES RI. 2016. Situasi dan Analisis Diabetes. www.depkes.go.id. [Diakses 11 Desember 2020]. 
Kementerian Kesehatan Republik Indonesia. (2018). Riskesdas 2018.

Nurarif, A. H., \& Kusuma, H. (2015). Aplikasi Asuhan Keperawatan Berdasarkan Diagnosa Medis \& NANDA NIC-NOC Jilid 1. Yogyakarta: Mediaction.

Padila. (2012). Buku Ajar: Keperawatan Medikal Bedah. Yogyakarta: Nuha Medika.

PERKENI (Perkumpulan Endokrinologi Indonesia). (2015). Konsensus pengelolaan dan pencegahan DM Tipe 2 di Indonesia. http://pbperkeni.or.id/doc/konsensus.pdf. [Diakses pada 21 November 2020]

Rendy, M. C., \& Margareth, T. (2015). Asuhan Keperawatan Medikal Bedah dan Penyakit Dalam. Yogyakarta: Nuha Medika.

Tarwoto, Wartonah, Taufiq, I., \& Mulyati, L. (2012). Keperawatan Medikal Bedah Gangguan Sistem Endokrin. Jakarta: Trans Info Media.

Usman, Yuslely, et al. (2019) Indonesia's Sample Registration System in 2018: A work in progress. Journal of Population and Social Studies 27(1), 39-52.

Wijaya, A. S., \& Putri, Y. M. (2013). KMB 2 Keperawatan Medikal Bedah Keperawatan Dewasa Teori dan Contoh ASKEP. Yogyakarta: Nuha Medika. 